\title{
Communicating Mathematics and Science in the Classroom: Exploring the Interactive Route
}

Landa Nhlanhla

Department of English

Faculty of Social Sciences and Humanities

University of Fort Hare

Alice Campus, Alice 5700

South Africa

landamasuku@gmail.com

Sindiso Zhou

Department of Languages and Communication Skills

Bindura University of Science Education

Bindura

Zimbabwe

sindisolorraine@gmail.com; szhou@buse.ac.zw

\section{ABSTRACT}

Communicating mathematical problems and scientific concepts is considered as a complex and difficult endeavour. Teaching, whether of complex mathematical problems and scientific concepts or of 'straightforward and clear' ideas in the humanities, is a process of communication. This paper argues that communication skills are an integral part of the teaching of Science and Mathematics. Communicating Science and Mathematics in the classroom involves thorough explanations and, because the concepts dealt with are in themselves complex, this may involve going over the concepts repeatedly. This ability to put across the mathematical or scientific message is the ability by the teacher to communicate. Research has insisted that the ability to communicate and to pose questions are central attributes of an effective teacher. This paper argues that more than being able to communicate and ask questions, for effective teaching of Mathematics and Science the teacher needs to employ interactive teaching techniques to involve learners; this way the teacher actively involves learners in communication and therefore in both the teaching and learning process. The teacher and learner roles in the contemporary classroom need not be distinctively outlined as this creates an obstacle to understanding. This allows both the teacher and student to understand concepts from each other's perspective. Through interaction between teacher and student, the teacher is able to explain the mathematical problem to the student from the student's perspective. Through a semi-structured interview and observation the study involves a sample of 32 students from four secondary schools in the two provinces of Midlands and Bulawayo. 


\section{Keywords:}

interaction, science, mathematics, classroom micro-culture

\section{Introduction and Background}

Students' performance in science subjects, specifically mathematics, is reported $\mathrm{N}_{\text {to }}$ be poor in Zimbabwe. This is a major issue of concern as Zimbabweans, maybe more than any other nationalities in the past decade, have increasingly had to compete for jobs in the international market. Studies on mathematics in Zimbabwe dominate research on performance of students in sciences and they include Wadesango and Dhliwayo (2012), Jaji (1991) and Nkoma et al (2013). Wadesango and Dhliwayo (2012) have conducted a study on ten rural Gweru district schools to determine the causes of poor performance in Ordinary level mathematics in Zimbabwe and they have cited poor teaching methods by teachers and negative attitudes towards mathematics by students as some of the causes of poor performance in the subject. They also attribute poor performance in mathematics to the fact that in most cases teachers have very little (less than five years) experience of teaching and they do not stay at the same school for long.

While this study was on the teaching of science subjects in general, it recognises that Mathematics is a significant science in the Zimbabwean context. Besides facilitating the learning of the other subjects in the school curriculum, passing of Mathematics at Ordinary level in Zimbabwe is a requirement for one to proceed to tertiary education. There are just a few degree programmes in Zimbabwean universities for whose study Ordinary level mathematics has not been made a mandatory requirement. As a result much of the exemplification will be on mathematics.

This paper argues that classroom interaction, which involves class-talk at several levels, is central to improving students' performance in their courses, including sciences. It is through interaction that students build their confidence in specific topics of the curriculum and start to participate in class. Required of the teacher is a trained reaction to students' errors and bizarre contributions, which in turn inculcates the same spirit in the other learners. The teacher then has a very important role of creating a learning environment in which learners participate and engage with each other and with the teacher actively and in interesting but progressive ways. This, the study argues, is achieved through several strategies that include question and answer sessions, group work, class-talk or dialogue and diverse classroom activities. The smaller the groups are, the more the chances that all the students will participate in group-work. Both formal and free-flowing debates can also be used as a form of interaction to promote students' participation and create interest in the subject matter.

\section{Related Literature}

Research on teacher-student classroom interaction and on the relationship between students and teachers include Brown and Hirst (2007) and Davis (2003/2006). Richmond, Wrench and Gorham (2001/ 2009), Mottet, Richmond and McCroskey 
(2006) and Huntley et al (2000) have also done research on the role of interaction in the classroom. These discussions of the interactive relationship between teachers and students and among students in a classroom set up all point towards communicative methods of classroom instruction. Research has shown that problem-solving and conceptual understanding of mathematics is greatly improved through classroom interaction (Huntley et al 2000). Shumba (1988) also found a significant link between teaching methods used and the performance of pupils.

Mottet, Frymier \& Beebe (2006) propounded what is known as the Rhetorical/ Relational Goal Theory of Instructional Communication. In this influential contribution they argue that traditionally both teachers and students share two types of goals in the classroom context; the rhetorical and relational. Developing from this, Richmond, Wrench and Gorham (2009) argue that students have "academic needs (ability to make good grades) and relational needs (feel affirmed as a person) also (p. ii). On the rhetoric level, teachers "focus on influencing students to learn and understand the content as presented by the teacher" while on the relational level teachers have specific types of relationships they want to create with individual learners; either closeness or distance (Mottet, Frymier \& Beebe 2006, p. 267). Teachers have different approaches when it comes to the relational goals; some choose to create a distance from the students while others create closeness with students in an attempt to promote students' interest in the subject. These relationships, however, do not work the same way for all learners hence the need to constantly engage students in interactive activities in order to ascertain what kinds of relationships work for what kind of students and what teaching methods would work for particular individuals.

Mottet, Frymier \& Beebe (2006, p. 269) argue that as most learners grow and mature their relational needs get lesser and lesser but some students will still depend on the affirmation from their instructor "and need ego support to maintain motivation for the course". On the other hand, Richmond, Wrench and Gorham $(2009$, p. ii) argue that "too often teachers believe that they are hired to teach a specific subject not to get students to like the subject," which is retrogressive as research shows that not liking the subject greatly diminishes the level of cognitive and psychomotor learning. Wrench et al (2008) also concur that if a learner does not have positive affect for the content or the instructor in a classroom set up it will be very difficult for that individual to learn. The picture being painted here is such that if an instructor attends to just the rhetorical goals and ignores the relational goals of the students, which call for interaction with them and specific communication skills, the learning process will be compromised. What this translates into is a situation where the teacher or the instructor should thrive to engage and "communicate with their students as supportively as possible ... regardless of whether their students are performing at a standard that is less than ideal ... create an environment where students also engage in these behaviours, supporting their classmates" and criticising them positively (Hurt et al, 1978, p. 186). 
Taking from the submission by den Brok et al (2009) that even cultural differences between teacher and student can result in "miscommunication or conflicts, especially if both parties have little knowledge of the viewpoint and experiences of the other" (p. 120), it is imperative for teachers to make an effort to understand their students individually. Research shows that this can easier be done through engaging students in interactive activities that allow them to open up, in the process giving feedback to teachers.

Research on interactive teaching methods or the role of interaction in the learning process by students exists outside of the sciences classroom. In studies carried out in Applied Linguistics, researchers (Long 1990, Krashen 1987, Rodgers 2001) have argued that learners of a second language need to be in conducive learning environments and "to be in situations that provide maximum personal involvement in the communication and ... social interactions" (Albakri 2005, p. 112). Widdowson also argues that appropriate pedagogy involves "an approach to teaching which combine authenticity with an appeal to universal natural learning and humanistic approach" (1994, 388-389). According to Richards and Rodgers (2001), interaction with students allows teachers to be needs analysts as interaction gives them a chance to understand the learning needs and weaknesses of individual learners through feedback provision. Interaction is thus defined in linguistics as the discourse jointly constructed by the learner and his interlocutors (Ellis 1985) and learning as a process of creative construction that involves trial and error (Rodgers 2001).

\section{Research Methodology}

\section{Interview Protocol}

The researcher interviewed secondary school pupils in four schools drawn from two different provinces in Zimbabwe. Two schools were selected from the Midlands Provincial capital Gweru while two were from the metropolitan province of Bulawayo. Purposive sampling was used as the researcher targeted specific Ordinary Level candidate classes doing at least three science subjects, including Mathematics. The schools chosen all used student screening methods in which, after form two, students are put into three different classes according to general performance and therefore grouped into Sciences Class, Commercials Class and Arts Class.

The screening method used in these schools is such that when pupils come for form one they are given classes according to who secured the form one place first and when one class is full pupils automatically go into the next class until their three classes are full. The classes in which lower form learners in these schools find themselves have nothing to do with their individual performance at grade seven. However these schools have what they call cut-off points where the schools say it only takes students with units ranging from, say, six to four. What this means is that at form one and two the pupils are doing the same subjects and 
the same number of subjects. In three of the four sample schools pupils in the same level are taught by the same teachers in the specific subjects. Then after the form two mid-year or end of year examinations teachers look at all the results and the pupils are given positions according to how many marks they have scored, regardless of which subjects they passed and which they failed. The first third, with the highest marks, goes into the Sciences Class while the second third goes to the Commercials Class and the third goes to the Arts. Entailed assumptions are that: "Ability to score highest in many subjects equals the Ability to do better in Science Subjects" and "Lowest marks from a total of many subjects equal inability to handle Science subjects". As indicated earlier in the study, science subjects are generally considered to be more complex and difficult than arts.

Four of the eight classes in the sample majored in Arts but were also doing Mathematics and some science subject like Integrated Science, Geography or Agriculture. However, in all the sample schools Science Subjects like Biology, Physics and Chemistry were a preserve for the Sciences Class. Pupils from the Sciences Class also did more subjects than the Commercials and Arts classes in all the four sample schools. The other four classes majored in Sciences and were also doing one or two Art subjects, including the languages; English and Ndebele for Bulawayo Province or English and either Shona or Ndebele for Midlands.

The primary data collected and used for this study includes a sample of 32 interviews. A total of eight pupils from each of the four sample schools were interviewed. Of the eight pupils sampled at each school four were from the Sciences Class while four were from the Arts Class. The 32 interviewees comprised 19 boys and 13 girls, each of whom participated in a semi-structured interview. Pupils were interviewed individually by the researcher at their schools and each interview lasted an average of 30 minutes. Two visits were made to each school on two consecutive days. The data also includes interviews with the head teachers of the four schools sampled in the study. The school head teachers were included in the study in order for the researcher to source background information about the pupils and how they got to be in the classes they were. This is where information about the methods of student screening was sourced. At one school the head was on leave and data was sourced from the deputy head teacher, who was acting in his place.

\section{Observation}

The observation method was also used to collect data. Information relating to school infrastructure; the state of desks, pupil-textbook ratio, entertainment equipment, sporting equipment and other extra curricula activities, availability and state of laboratories and libraries was sourced through this method. The researcher used observation prior to the study to select sample schools. Only those schools that the researcher adjudged had good infrastructure were selected for the study. This was assumed to increase the accuracy of the results of this particular study as the state of infrastructure could also contribute to factors affecting students' performance in general. This stems from research that argues that the quality of the 
physical environment affects students' performance (Fisher 2000, Horne 2004), that the quality of the infrastructure around which students spend 'a good deal of their time learning does in fact influence how well they learn' (Earthman, 2004:18). Bunting (2004) and Lance (2002) have also argued that there is a link between the physical school environment and learning. Inadequate text books are also a major cause of poor performance by students generally (Fagbamiye 2004, Ale 2002). The researcher chose for the study those schools where such factors were likely to have little contribution to the level of performance by students in any subject, especially the science subjects.

\section{Data Collection}

A semi-structured interview was used for the school head teachers. Generally from these the researcher sought to establish the general learning environments that the pupils were exposed to, the schools' traditional treatment of the 'sciences and arts divide' in their day to day activities. The researcher also sought to establish how many Ordinary Level candidates each school had, how many were doing science subjects, how many were doing commercial subjects and how many were in the arts classes. General questions were also asked about each school's pass rate and the student-to teacher ratios for individual classes. The study also sought to establish from the heads which subjects were being offered to which classes, which ones were compulsory for all students and what criteria was used for vetting and screening students into different classes at form three.

School head teachers were also asked to provide information on which teacher taught what subject and to which classes. This information was useful to the researcher as he could then crosscheck with his list without asking students who their teacher for a specific subject was as students described their teachers. The researcher's assumption on this aspect was that students would be at ease to say "My Geography Teacher", "Our English Teacher" or "The Biology Teacher" than to say Mr or Mrs X. Another assumption was that having a list of teachers for specific subjects would help the researcher establish patterns from students' responses on teaching methods and ascertain whether or not a student's dislike of a subject had anything to do with teaching methods or teacher attitudes.

At the beginning pupils were asked a general question on what grades the pupils had attained on their Form Two mid- year examinations in those schools that used the mid-year examinations for screening of students and on their end of year examinations for those schools that used the end of year examinations. Performance was asked in relation to three specific sample subjects and these are Mathematics, Integrated Science and Geography. These were selected on the basis that they are the three science subjects commonly done by form one and two pupils at the sample schools. Other branches of science, usually breaking away from topics done in Integrated Science or General Science, are introduced at form three. This approach was meant to establish the students' inclination towards liking or disliking science subjects before the screening process and to ascertain their performance in science subjects before screening into either the Sciences 
class or the Arts Class. As has been submitted already, screening into either the sciences or arts classes at these schools has nothing to do with a student's performance in individual subjects. Another reason for choosing the three subjects was that they are the only three science subjects that both the Ordinary level arts classes and sciences classes in the sample schools commonly have access to. While students in the sciences classes in the sample schools are introduced to other subjects like Chemistry, Physics and Biology at form three, they still do Integrated Science.

Several questions were included to ascertain what methods the teachers used in the class to teach and create, promote and maintain students' interest in the subjects they taught; what strategies the teachers used to motivate students and to create positive affect towards the specific science subjects, what influence the teachers had on the learning process and on the learners. The researcher provided a common definition of the terms 'influence' and 'motivate/ motivation' to allow the participants to respond in a common context of the linguistic usage of the terms. Initially a student was asked what subject he/she liked and a follow-up question required them to state why they liked that particular subject more than others. This research question sought to establish if there was a link between a student's liking of the subject and their liking of the teacher or the teaching methods.

After issues to do with the confidentiality of the information they provided were settled, students were asked to give character descriptions of five of their teachers. The five included the teachers of the three subjects in the sample (Mathematics, Geography and Integrated Science), the teacher of their favourite subject and the teacher of their 'least favourite' subject. The favourite and least liked subjects were included in the study to ascertain what students found interesting and progressive and what they found boring or retrogressive about both teaching methods used and teacher characteristics and behaviour. This is in line with Richmond, Wrench and Gorham's (2009) and Wrench et al (2008)'s arguments that interest in and positive affect towards the subject content or the subject teacher has influence on the students' learning of that particular course or subject. Questions were followed up to get a clear picture of what the students were describing and to direct them towards providing material that spoke to teaching methods and student-teacher relational aspects.

\section{Discussion of Findings}

From the data sourced from departmental records availed by the head teachers, students in the science classes dominated in the three sample subjects and from interpretation of responses secured from participating students this could be attributed to issues of attitude towards the sciences by students in traditional arts classes. Analysis of data point towards the fact that because the students in the arts classes are 'arts students' they major in arts and consider the science subjects, with considerable exception of mathematics, as extra subjects. This attitude is created by the schools' administrations in the first place through screening as classes are labelled 'arts', 'sciences' or 'commercials'. Further, the structuring of these classes 
is such that students from the arts class, while doing one or two science subjects at Ordinary level, cannot do sciences at Advanced level. Knowledge of this makes students in the arts classes not worry a lot about the science subjects. The Zimbabwean education system is such that at form four students are as worried about passing five subjects as they are about passing subjects that will allow them to get a 'combination' at Advanced level. A mini-survey carried alongside this study established that there is an increase in the number of students who are retaking Ordinary level mathematics alongside their Advanced level studies.

The average size of the classes at the sample schools is 50 students per class and three classes per level. However, at three of the four schools in the study the Sciences classes were the smallest of the three. At one school the sciences class had only 42 students while the arts and commercials had 54 and 52 pupils each, making them accommodate 12 and 10 students more than the sciences class respectively. While they said it in different terminology, the three head teachers responded that the science class deserved a lower student-teacher ratio because they were more demanding and it was more important for them to be passed than the other subjects. On follow-up questions why it was more important that Science subjects be passed than it was for other subjects the head teachers implied that the modern community demanded more science than art. The picture painted by this is one where a predetermined relationship between the teacher and the students is preordained by the administration before the instructor gets to the classroom. The student-teacher ratio phenomenon is more to do with the teacher being able to have beneficial relationships with each student in order to understand their academic needs and to give each student individualised attention than it is about how many essays or assignments the teacher marks (Azim Premji Foundation 2010, Diaz et al 2003). If this is true then there is need for even a better student-teacher ratio in those classes where students are struggling, especially with Mathematics and the one or two other science subjects they are learning.

This attitude of the administration, the study established, is communicated down to the teachers and the teachers carry it to the classrooms. In schools where the same Math teacher taught Math to both the Sciences and Arts classes, pupils from the two classes described their teacher in ways that evidenced two different types of teacher-student relationships. While pupils from the Sciences class professed closeness to their 'friendly' Mathematics teacher in the case of School One, pupils from the Arts class generally described the same teacher as 'always angry' and 'tired'. Taking from the example provided above what this translates to is a 'tired' relationship between the teacher and 106 students in the Arts and Commercials Classes and a good and healthy relationship between the same teacher and 42 Mathematics pupils in the Science class. While the intention of the system might be to develop the identified potential of the students in the Sciences, the scenario described leads to passing of Mathematics and Sciences by fewer pupils mostly from the ' $\mathrm{A}$ ' (science) class as most pupils from the other two classes are likely to develop negative affect towards the subject. The result of such a situation is excellent access to sciences by only a third of the student population. 
The screening of students into the classes, as already described, is not based on students' strength on particular subjects anyway. Integrative methods where students are not screened but are allowed access to the same subjects might work better for complex subjects like Mathematics and other sciences but this is subject for another research. Mathematics is complex enough already without the negative learning environment, which would most likely lead to negative affect towards both the teacher and the content.

A comparative analysis of the four schools' treatment of the sciences-arts divide established that sciences are considered both more important and more complex than the arts. At one school the researcher asked the head teacher a general question about his school's performance the previous year and the head teacher responded, "There was a huge improvement and we are happy. At A' Level the highest had 13 points and he was doing MPC (Maths, Physics and Chemistry). We also had someone from the Arts who had 15 points". According to him there was someone from the arts with 15 points but the highest had 13 points because he was doing sciences. Whether these assertions are accurate or not is subject to another study but as far as this study is concerned this situations works in favour of the science subjects as it means a lot of effort will be directed towards improving of the pass rate of these subjects. The question is; what effort is being increased because if teachers increase the time they meet the sciences pupils and the number of exercises or experiments they make the students do without attending to the question of teaching methods this effort will be fruitless. As shall be discussed later, the study established that students from both the science and arts classes prefer those teaching methods that allow them to interact with the teacher, with other students and even with students from other schools.

Collectively, $71.8 \%$ (23) of the participating students had attained grade B or better in Junior Certificate Mathematics examinations, which examinations were used for screening of students into form three classes. What is interesting is that only $52.1 \%$ (12) of these are in the science classes while the remaining $47.8 \%$ (11) are in the arts classes. Even more interesting is the statistics relating to Integrated Science where $87.5 \%$ (28) of the participating students had attained grade B or better in Junior Certificate and $57.1 \%$ (16) of these are in the arts classes, with only $42.8 \%$ (12) in the science classes. What this means is that $100 \%$ of the participating students from the arts classes in the four schools attained grade $\mathrm{B}$ or better in the form two examinations used for screening students into form three classes. In Geography all the participating students attained grade B or better at Junior Certificate examinations. What this points at is that had students screening methods been such that students' potential in individual subjects was identified and followed up or such that all the subjects, whether sciences, commercials or arts, were offered to all the students at the same level, performance in the science subjects would improve in all the students. Whichever way, the performance of students in the sample subjects before screening, was significantly good (see fig 1 below). This could be attributed to the integrative approach used at 
form one and two or to the fact that certain attitudes teachers adopt when classes are labelled arts or sciences are absent at form one and two.

\section{Figure 1: Performance of Students in Sample Subjects at Form Two}

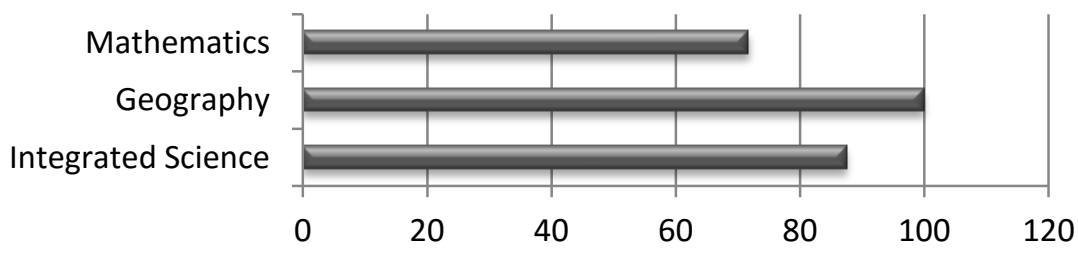

Source: Primary Data Collected For Study

One of the research questions sought to establish the kinds of relationships that teachers have with their students in the classroom and whether these aided or impeded the learning process. On the general 59.3\% (19) of the participating students described their Maths teachers as 'distant' and easily angered by students' failure to respond well to content. The pupils said this made learning of Math very difficult and very often they felt discouraged. Students indicated that this was a result of the fact that it took time for the class in general to understand certain concepts in Math and they needed the teacher to move slowly and go over the concepts repeatedly. This was established through follow up questions to their description of individual teachers. The common understanding of 'distant' as used by the students ranges from teachers maintaining a distance between themselves and the students to being unapproachable. Analysis of data revealed that in certain circumstances some Maths teachers are frustrated by students' failure to understand 'simple' concepts and as a result lose patience with students. If the learning atmosphere in the classroom is too serious for the comfort of the learners the learning exercise is thus rendered retrogressive.

\section{The Case of a Favourite Subject}

The research question on students' favourite subject resulted in interesting responses from both the sciences and arts classes. 65.6\% (21) of the student participants of the study indicated that their favourite subject was Literature in English. On face value one would quickly think that because Literature is an art, 16 of the 21 pupils who indicated that their favourite subject was Literature are from the arts classes and the rest (five) are the lost sheep from the sciences classes. This is not so as only 13 of the 21 students whose favourite subject was Literature were from the arts classes while eight were from the sciences classes. Interpretation of data revealed that what the students liked most is that the teaching methods in Literature involve role playing in the plays under study, turn-taking reading of novels in class, free flowing debates and watching of films on television during class time. Several students also cited the concept of exchange visits between schools and the fact that "the teacher tells us that there is no wrong 
answer as long as you can support yourself convincingly from the novels". This concept can be used across all the subjects, including the sciences and it is predicted to increase students' participation and by extension their interest in the subject. What such approaches to teaching have done is to allow the student to relate to the subject in a realistic way as she/he gets to interact with other students, with the teacher and with the course content in a social manner. On the other hand least liked subjects were associated with 'boring' teaching methods and 'mean' teachers or learning environments that students felt were 'discouraging' or 'demotivating'.

\section{Figure 2: Percentages According To Favourite Subject}

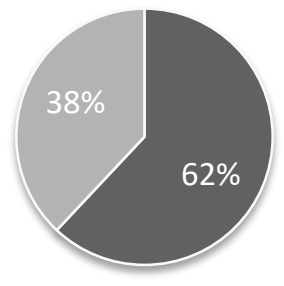

- Percentage of Students from the Arts class whose favourite subject is Literature

- Percentage of Students from the Sciences class whose favourite subject is Literature

\section{Source: Primary Data Collected For Study}

\section{Future Directions}

While several other factors contribute to low pass rate in mathematics and other science subjects, teaching methods that do not seek to engage students in interactive ways in the classroom seem to worsen the situation as they create learning environments not favourable to the learning exercise. Interactive teaching methods help teachers in identifying each student's learning needs and matching them with the most appropriate teaching styles. This can easily be achieved through interaction, broadly understood in this context to refer to the creation of progressive relationships with students individually. While secondary school teachers are necessarily hired to teach specific subjects to students, they can do this better and more effectively if they also make it part of their duties to understand the academic and relational needs of the individual learners that they teach. This can only be achieved through interacting with students and employing classroom activities that allow students to interact with each other. As they interact with each other and with the teacher students gain trust of the teacher and improve in confidence. This also improves students' participation in the learning activities, and has positive results for students' performance.

Through interaction, students are persuaded to learn from each other, from each other's perspective and the teacher has the opportunity to make each student understand a problem or concept from the individual student's perspective. Just as Bruce (2007) contends, the role of the teacher does not diminish in interactive teaching methods but gets even stronger as the teacher plays the pivotal role of 
shaping the learning environment and guiding students to work in groups for achievement of the desired goals. The teacher, through interacting with and engaging students, creates what has, in other research, been called a classroom micro-culture (Reyes \& Stanic 1998, Strickland \& Asher 1992).

Interaction in classroom can be achieved by coming up with interesting learning activities for students and allowing them to work in small groups. Psychologists argue that it is in a group, more than individually, that an individual understands the situation at hand best (Nyanungo, 2002). This applies even more to the learning of sciences as students' skills to process and interpret both verbal and non-verbal information from others need to be developed (Windschitl 2009). Moving away from "the-teacher-knows-it-all" military approach to the teaching of especially mathematics allows students to do away with what Lance (2002) and Hanfi (2008) call mathophobia, mathematics anxiety that makes students dread the subject and anything they consider mathematical hence they develop a negative attitude towards mathematics. This study argues that by extension students also develop negative affect towards other science subjects they consider to have mathematical concepts in them.

Therefore, employing interactive teaching methods, which involves strategic creation of positive affect towards both content and instructor in the teaching of complex subjects like the sciences, constant motivation of students and getting feedback through class talk would greatly improve students' performance in the sciences, including mathematics. Changing the views and attitudes of students towards mathematics and the sciences is as much important as is imparting knowledge to them. As Diaz et al (2003) have argued, students' attitude towards a particular subject has the effect of changing the attitude of the subject teacher towards the students. As a result, effective methods of teaching will be those that seek to impart knowledge of a particular subject by creating interest and positive affect in the learner towards both the subject and the knowledge sourcethe teacher. As this study established students are likely to learn better if they consider the teacher as a role model, someone they can trust and someone they can approach easily and ask questions in and out of class. Interactive teaching methods, including having students work in small groups, also diminishes the effect of the big classes that are found in Zimbabwean schools as the teacher reduces the class into small sub-sets of the whole. Without this strategy a significant portion of the class is likely to drown in the numbers and remain uninvolved in the learning process.

\section{References}

Albakri, R. N. 2005. Interaction is the Key to Second Language Learning. Journal IPBA/ Jilid 3: Bilangan 2: 110- 113.

Ale, S.O. 2002. Difficulties facing mathematics teachers in developing countries, Educational Studies in Mathematics, 12 (4): 23-29. 


\section{Communicating Mathematics and Science in the Classroom: Exploring the ...}

Azim Premji Foundation. 2010. The Criticality of Pupil Teacher Ratio; Empirical Evidence from 766 Lower Primary Schools of North East Karnataka, Issues in Elementary Education, Bangalore: Azim Premji Foundation.

Brown, R. \& Hirst, E. 2007. Developing and Understanding of the Mediated Role of Talk in the Elementary Mathematics Classroom. Journal of Classroom Interaction, 41, 188 - 22.

Bruce, C. D. 2007. Student Interaction in the Math Classroom: Stealing Ideas or Building Understanding, The Literacy and Numeracy Secretariat: What Works? Accessed January 2007, www.inspirelearning.ca/english/research/researchRoom.htm

Bunting, A. 2004. Secondary Schools designed for a purpose: but which one? Teacher, (154), 10-13.

Davis, H. A. 2003. Conceptualising the Role of Student-Teacher Relationships on Children's Social and Cognitive Development. Educational Psychologist, 38, 207 - 234.

Davis, H. A. 2006. Exploring the Contexts of Relationship Quality between Middle School Students and Teachers. The Elementary School Journal: Special Issue on the Interpersonal Contexts of Motivation and Learning, 106, 193- 223.

den Brok, P., Wubbels, T., Veldman, I. \& van Tartwijk, J. 2009. Perceived student-teacher interpersonal relationships in Dutch multi-ethnic classes, Educational Research and Evaluation, 15, 119-135.

Diaz, K., Fett, C., Torres-Garcis, G. \& Crisosto, N. M. 2003. The Effects of Student-Teacher Ratio and Interactions on Student/ Teacher Performance in high School Scenarios, Technical Report: Cornell University.

Earthman, G. 2004. 'Prioritisation of 31 Criteria for School Building Adequacy', American Civil Liberties Union Foundation of Maryland, http://www.aclumd.org, Accessed May 2007.

Ellis, R. 1985. Understanding Second Language Acquisition, Oxford: Oxford.

Fagbamiye, E. O. 2004. The Teaching Profession, Conference on the Teacher's Interactive Forum, Lagos.

Fisher, K. 2000. 'Building better outcomes: the impact of school infrastructure on student outcomes and behaviour', Schooling Issues Digest, Canberra: Department of Education, Training and Youth Affairs.

Hanfi, Z. 2008. The Relationship between aspects of socio-economic factors and academic achievement. Journal Pendidikan, 33: 95-105.

Horne, M. 2004. 'Breaking Down the School Walls', Forum, 46, (1), 6.

Huntley, M. A., Rusmussen, C. L., Villarubi, R. S., Sangtong, J 7 Fey, J. T. 2000. Effects of standard-based mathematics education: a study of the Core-Plus Mathematics Project algebra and functions strand, journal of Research in Mathematics Education, 31 93), 328-361.

Hurt, H. T., Scott M. D. \& McCroskey, J. C. 1978. Communication in the Classroom (Chapter 1, 2 and 3). Reading, MA: Addison-Wesley.

Jaji, G. 1991. Curriculum Implementation in Mathematics classrooms in Zimbabwe secondary schools. Zimbabwe Journal of Educational Research, 5 (1): 34-39.

Krashen, S. D. 1987. Principle and Practice in Second Language Acquisition, London: Prentice Hall International. 
Lance, K.C. 2002. Impact of school library media programs on academic achievement. Teacher librarian, 29 (3): 23-27.

Long, M. H. 1990. Task, Group and Task-group interactions. In Anivan S. (Ed). Language teaching methodology for the nineties; 31-50, Singapore: Regional English Language Centre, Singapore University Press.

Mottet, T. P., Richmond, V. P. \& McCroskey, J. C. (eds.). 2006. Handbook of Instructional Communication: Rhetorical and Relational Perspectives (pp. 255 - 282). Boston: Allyn and Bacon.

Motet, T.P., Frymier, A. \& Beebe, S.A. 2006. Theorising about Instructional Communication. In T. P. Mottet, V. P. Richmond \& J. C. McCroskey (eds.), Handbook of Instructional Communication: Rhetorical and Relational Perspectives. Boston: Allyn and Bacon.

Nkoma, E., Zirima, H., Chimunhu, J. \& Nyanga, T. 2013. Tracking Learner Achievement Gap: An Analysis of Mathematics Achievement in Manicaland, Zimbabwe, International Journal of Economy, Management and Social Sciences, 2 (5): 124-132.

Nyanungo, K.L.R. 2002. Psychology: The Public and other Professions, Zimbabwe Open University, Harare.

Reyes, L. H. \& Stanic, G. M. A. 1998. Race, sex, socio-economic status and mathematics. Journal for Research in Mathematics Education, 19, 26-43.

Richards, J. \& Rodgers, T. 2001. Approaches and Methods in Language Teaching (2 ${ }^{\text {nd }}$ ed.). Cambridge: Cambridge University Press.

Richmond, V. P., Wrench, J. S. \& Gorham, J. (eds.). 2009. Communication, Affect and Learning in the Classroom ( $3^{\text {rd }}$ Edition). California : Richmond, Wrench \& Gorham.

Richmond, V. P., Wrench, J. S. \& Gorham, J. (eds.). 2001. Communication, Affect and Learning in the Classroom $\left(2^{\text {nd }}\right.$ Edition $)$, MA: Tapestry Press Acton.

Rodgers, T. 2001. Language Teaching Methodology, Center for Applied Linguistics Issue paper: Online resources, Digest.

Shumba, S. 1988. An investigation of Teaching Approaches and Their Relationship to Pupil Performance with Specific Focus on Common Fractions in Sixth and Seventh Grade Classes. Master's Thesis, Unpublished: Harare, University of Zimbabwe.

Strickland, D. S. \& Asher, C. 1992. Low income African-American children and public schooling. In P. W. Jackson (Ed), Handbook of Research on Curriculum (pp. 609-625).

Wadesango, N. \& Dhliwayo, E. 2012. Study of Secondary Schools Students Performance in Mathematics from Zimbabwe, 14 (2): 113-121.

Widdowson, H. G. 1994. ‘The Ownership of English’, TESOL Quarterly, 28 (2): 377-389.

Windschitl, M. 2009. Cultivating $21^{\text {st }}$ Century Skills in Science Learners: How Systems of Teacher Preparation and Professional Development Will Have to Evolve. National Academies of Science Workshop, University of Washington.

Wrench, J. S., McCroskey, J. C. \& Richmond, V. 2008. Human Communication in Everyday Life: Explanations and Applications. Boston: Allyn \& Bacon. 